Bulletin of the Natural History Museum, 2020, 13: 237-252.

Received 23 Aug 2020; Accepted 5 Oct 2020.

doi:10.5937/bnhmb2013237V

UDC: 597.943(497.11)

Original scientific paper

\title{
THE DISTRIBUTION OF CRESTED NEWTS IN SERBIA: AN OVERVIEW AND UPDATE
}

\author{
TIJANA VuČIĆ* , LJILJANA TOMOVIĆ, ANA IVANOVIĆ \\ University of Belgrade, Faculty of Biology, Studentski trg 16, 11000 Belgrade, \\ Serbia, e-mail: tijana.vucic@bio.bg.ac.rs
}

Four, morphologically similar species of crested newts (genus Triturus) meet and hybridize in Serbia, making a complex system with several hybrid zones. The puzzling and rapidly changing taxonomic status of crested newts has been a major issue in getting hold of their distribution. We provide an overview of the current knowledge on Triturus taxonomy and compile available faunistic data into a distribution map, highlighting the species contact and hybrid zones. At the present state of faunistic and genetic research, the north-western, north-eastern, eastern and south-eastern parts of Serbia transpire as areas that are exceptionally important for the diversity of crested newts.

Key words: distribution map, faunistic data, hybrid zones, Triturus

\section{INTRODUCTION}

Large-bodied newts (genus Triturus Rafinesque 1815) are tailed amphibians (Urodela: Salamandridae) widely distributed throughout Europe and adjacent Asia. Triturus is a monophyletic genus that is approxi- 
mately 24 million years old (Steinfartz et al. 2007, Wielstra et al. 2019). Biogeographical patterns of species distribution largely reflect Pleistocene refugia patterns and postglacial range expansions (Wielstra et al. 2014a). Species have clearly distinct distributions with parapatric ranges, but in contact zones hybridization may be more or less frequent (Arntzen et al. 2014, Wielstra et al. 2014b).

Over the last 40 years, the puzzling and rapidly changing taxonomic status of Triturus species has been a major issue in getting hold of their distribution. In Serbia, four of altogether nine species meet and hybridize, making a complex system with several hybrid zones, showing features like spatial species replacement and asymmetric mitochondrial DNA (mtDNA) introgression (e.g. Wielstra \& Arntzen 2012, Arntzen et al. 2014, Wielstra et al. 2017).

Historically, the determination of species and their distribution ranges in Serbia was challenging because of the great morphological similarity among them, let alone that of interspecific hybrids. Moreover, the first phylogeographic studies were based on mtDNA analyses alone, which enabled identification of potentially cryptic species, but could also be misleading due to possible mtDNA introgression. This problem emerged in Triturus newts in Serbia (Wallis \& Arntzen 1989, Wielstra \& Arntzen 2012, Wielstra et al. 2017). In many populations individuals that were morphologically recognized as a single species were, based on mtDNA, identified as another crested newt species, which suggested possible introgression. At the time, the studies that combined morphology and allozyme data contributed to a better understanding of species distributions, but only to already recognized taxa (e.g. Kalezić \& Hedgecock 1980, Kalezić et al. 1990, Kalezić et al. 1997). A more profound multilocus exploration of nuclear DNA was needed to clarify a complicated situation. Continuous work on resolving the Triturus phylogeny lasted over several decades (Rafinski \& Arntzen 1987, Giacoma \& Balleto 1988, Arntzen \& Sparreboom 1989, Arntzen \& Wallis 1999, Litvinchuk et al. 1999, Zajc \& Arntzen 1999, Arntzen et al. 2007, Steinfartz et al. 2007, Themudo et al. 2009, Wiens et al. 2011, Wielstra \& Arntzen 2011, Wielstra et al. 2012, Wielstra et al. 2013a). Recent application of new molecular methods and approaches in systematic research (e.g. KASP genotyping and Nextgeneration sequencing) enabled the comparison of large number of nuclear markers and many individuals at the same time and this allowed species delineation and analysis of interspecific hybridization (Wielstra et al. 2014c, Wielstra et al. 2017, Wielstra et al. 2019).

Here we provide a brief historical overview of the taxonomy of the genus Triturus. The first classifications of the family Salamandridae were 
based on different morphological (Bolkay 1928, Wake \& Özeti 1969) or behavioural characteristics (Halliday 1977). These studies suggested a monophyletic origin of the genus Triturus. However, at that time, the genus comprised species of large-bodied, small-bodied, alpine, and banded newts. The genetic analyses, which included molecular methods exploring allozymes, microsatellites and mtDNA (e.g. Titus \& Larson 1995, Weisrock et al. 2006), led to a rejection of the monophyly of these species groups as members of a singular genus (Steinfartz et al. 2007, Zhang et al. 2008).

García-París et al. (2004) suggested separation of small-bodied species in the genus Lissotriton Bell, 1839 and species Ichtyosaura alpestris (formerly T. alpestris and Mesotriton alpestris) in the genus Messotriton Bolkay 1928. Litvinchuck et al. (2005) additionally separated the species Ommatotriton vittatus (former T. vittatus) in the genus Ommatotriton Gray 1850.

Today, the genus Triturus comprises nine large-bodied newt species, with a basal division in marbled and crested newts (e.g. Wielstra et al. 2019). Marbled newts (T. marmoratus and T. pygmeus) have a specific, marbled dorsal coloration. The crested newts on the other hand are named after the large, prominent crest on the back of the males, which is expressed during the mating season. They have a uniform, dark dorsal colouration and a vivid orange belly with black dots. Initially the crested newt was seen as a single species with four subspecies: T. c. cristatus, T. c. carnifex, T. c. dobrogicus and T. c. karelinii. It was noted though that various forms differed in body proportions and, as Wolterstorff (1923) showed, could be told apart by the ratio of the limb length to the interlimb distance. This morphometric index was proposed to bear Wolterstorff's name (Arntzen \& Wallis 1994).

A comparative analysis of particular genomic characters and the results of cytogenetic studies of interspecific hybrids led Bucci-Innocenti et al. (1983) to recognize the four T. cristatus subspecies as full species: $T$. cristatus (Laurenti 1768) with the most northern distribution (from Great Britain, Sweden and Norway in the north to the northern part of the Balkan peninsula in the south, and from central Russia and the Ural mountains in the east to the Atlantic shore in France in the west); T. dobrogicus (Kiritzescu 1903) that occurs in the wider Danube river valley (from the city of Vienna to the Black sea, all over the Pannonian plains); T. carnifex (Laurenti 1768) that inhabits the Apennine peninsula and the northern Balkans (from the Alps in Italy at the south to the Dinaric Alps in the east and reaching into the south of the Czech Republic); and T. karelinii (Strauch 1870) that occurs from the Balkan peninsula to the southern shores 
of the Caspian sea, including Crimea, Caucasus, Anatolia as well as some isolated pockets in Serbia. These species are often considered as $T$. cristatus superspecies.

Over the decades, the taxonomic status of $T$. cristatus and $T$. dobrogicus remained unchanged, although Borkin and Litvinchuk (2000) proposed two $T$. dobrogicus subspecies: western, $T$. $d$. macrosomus and eastern, $T$. $d$. dobrogicus based on species disjunctive distribution. Several genetic studies (Vörös \& Arntzen 2010, Wielstra et al. 2016, Vörös et al. 2016) and morphological analysis (Naumov \& Biserkov 2013) rejected this subdivision. On the contrary, T. carnifex and T. karelinii were split up into several new species. Based on morphology, allozyme and mtDNA research, two subspecies of $T$. carnifex were recognized $-T$. c. carnifex and T. $c$. macedonicus (Crnobrnja et al. 1989, Kalezić et al. 1997, Arntzen \& Wallis 1999). Arntzen and Wallis (1999) classified species originally described as Molge karelinii var. macedonica Karaman 1922 as subspecies T. c. macedonicus. Further, based on mtDNA analysis and deep genetic differentiation as well as differences in ventral coloration patterns, Arntzen et al. (2007) suggested that two subspecies should be considered as species - T. carnifex (Apennine Peninsula) and T. macedonicus (Balkan Peninsula).

Wallis and Arntzen (1989) noticed a deep geographic structuring in mtDNA within T. karelinii, even within the limited sampling over the western part of the range. Litvinchuk et al. (1999), based on genome size, protein variation, mtDNA and morphological characters, suggested that $T$. karelinii populations in Serbia represent a separate subspecies which was named T. $k$. arntzeni. Steinfartz et al. (2007) confirmed the paraphyletic grouping within T. karelinii. Themudo et al. (2009), based on data from mtDNA and nuclear DNA analysis, proposed that T. k. karelinii and T. $k$. arntzeni should be considered as two separate species $-T$. karelinii (Strauch 1870) with eastern distribution and T. arntzeni (Litvinchuk et al. 1999) with a western distribution. Furthermore, Arntzen and Wielstra (2010) analysed nuclear DNA by protein electrophoresis and concluded presence of western and eastern group which correspond to T. arntzeni and T. karelinii. The extensive phylogeographic research based on mtDNA sequencing by Wielstra et al. (2010) revealed that T. karelinii group is composed of three geographically coherent clades: an eastern one (Caucasus, Crimea and the southern shores of the Caspian sea), a central clade (north Turkey and the southern shores of the Black sea) and a western clade (western Turkey - Asian part and the Balkan Peninsula). By applying spatial ecology methods, used to quantify ecological niche differences between Triturus species, including species candidates, Wielstra et al. (2012) concluded that three $T$. karelinii phylogenetic lineages are actually three cryptic species. Further multilocus approach confirmed that three 
mtDNA phylogentic lines also represent differentiated pools of nuclear DNA genes (Wielstra et al. 2013a). Furthermore, the authors suggested that individuals previously assumed as $T$. arntzeni from its type locality in Serbia (Vrtovac, near Knjaževac) are T. macedonicus. They recommended that species name $T$. arntzeni should be considered as a $T$. macedonicus synonym and be used for the western lineage of $T$. karelinii. Considering the western and central $T$. karelinii phylogenetic lines, Wielstra et al. (2013b) described T. ivanbureschi as a species distributed in the southeastern part of the Balkan Peninsula (Bulgaria, eastern parts of Greece, Macedonia, Serbia), European part of Turkey and Asian part of Turkey (near shores of Aegean sea, Sea of Marmara, and Black sea). Detached from main distribution range, there is T. ivanbureschi enclave in Serbia (Arntzen 2003), possibly formed by spreading of T. macedonicus and bordered by two other newt species, T. cristatus in the east and $T$. dobrogicus at the north (Wielstra \& Arntzen 2012, Wielstra et al. 2017).

Next-generation sequencing with the development of 52 nuclear markers (Wielstra et al. 2014c) confirmed that T. ivanbureschi mtDNA is widespread, outside the distribution borders as defined by nuclear DNA. Also, individuals from $T$. arntzeni type locality are genetically admixed $T$. macedonicus $\times$ T. ivanbureschi hybrids. Wielstra and Arntzen (2014) proposed that due to hybridization, the name $T$. arntzeni should be considered as synonym for T. macedonicus as was already suggested, but also as a synonym for T. ivanbureschi (Wielstra \& Arntzen 2014). Further multilocus nuclear DNA sequencing showed that T. ivanbureschi species actually represent two separated gene pools, which should be considered as two different, morphologically cryptic species: the western T. ivanbureschi (south-eastern Balkan Peninsula) and the eastern, new species, T. anatolicus, distributed in Anatolia (Wielstra \& Arntzen 2016).

Such dynamic of constant, subsequent changes in taxonomy produced inconsistency in assigning populations of crested newts to particular taxa in various legislative documents and the scientific literature, as well as in some faunistic databases. Our aim is to make a compilation of the current knowledge of Triturus distribution in Serbia, as follows:

Collect and systematize faunistic data of Triturus species in the Republic of Serbia available in the literature and faunistic databases;

Synthesize data into a distribution map [georeferenced at the $10 \times 10$ km standardized UTM (Universal Transverse Mercator) grid];

Highlight the species contact and hybrid zones;

Provide a guideline for further faunistic research. 


\section{MATERIAL AND METHODS}

The list of all recorded Triturus populations, with the geographical information for each population and the sources from which the record was taken is provided in Appendix 1. The species distribution was defined in relation to the genetic data published by Wielstra et al. (2017), which were accommodated for the purpose of this study. We defined contact zones and hybrid populations by the proportion of species contribution to the gene pool. If two or three species contribute with at least $20 \%$ in the gene pool, we defined the population genetically admixed. The populations in which the contribution of other species in the gene pool was less than $20 \%$, we considered population as "pure". The remaining populations are designated based on morphology and their position relative to genetically known composition of surrounding populations. Most of new faunistic data were collected in year 2020, as results of the projects mentioned in the acknowledgements and from the public internet faunistic database BIOLOGER (Popović et al. 2020).

All faunistic records were plotted on the $10 \times 10 \mathrm{~km}$ National Grid UTM (Universal Transverse Mercator) reference for the Republic of Serbia, by using an application created in Visual Basic 6.1 in the program WinWord 2003 (Niketić 1999).

\section{RESULTS}

We collected a total of 495 records of Triturus species in Serbia, of which literature data constituted $87.5 \%(n=433)$, unpublished field data made up $10.1 \%(n=50)$ and internet data constituted $2.4 \%(n=12)$ of the records (Appendix 1). The genetic information was available for 73 records, which is $14.7 \%$ of total records of Triturus species in Serbia. As expected, T. macedonicus was the most represented species, accounting for 197 records (39.8\%), followed by $T$. dobrogicus with 153 records $(30.9 \%)$, T. cristatus with 50 records (10.1\%) and T. ivanbureschi with $48(9.7 \%)$ records. Admixed populations were the least represented, with altogether 47 records (9.5\%) (Appendix 1).

Triturus dobrogicus is distributed in the Pannonian and partly Peripannonian part of Serbia, with disjunt population in the north-eastern part (Ključ region) (Fig 1). Triturus cristatus exists in north-eastern and eastern Serbia, with disjunct populations in the south-eastern part of the Banat region. The distribution of $T$. ivanbureschi includes two separate parts, in the Šumadija and Pomoravlje regions and in eastern and south-eastern Serbia. Triturus macedonicus has the widest distribution, occupying the largest part of the Mountain-valley region, with a distribution gap in the western and south-western geographic regions of Serbia. 


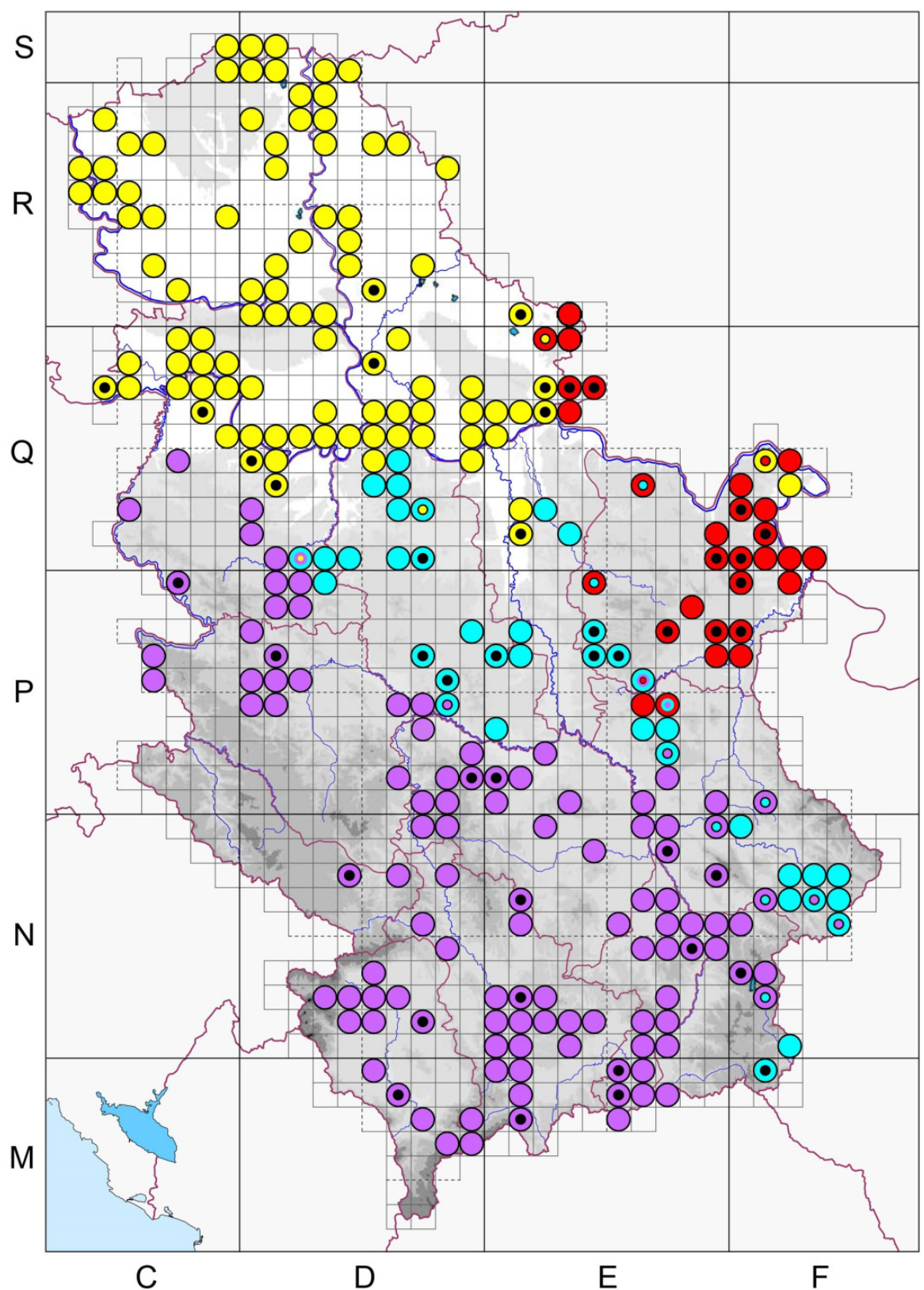

E

$\mathrm{F}$

Fig. 1 - Distribution (UTM greed $10 \times 10 \mathrm{~km}$ ) of Triturus species in the Republic of Serbia. Species colour codes are: yellow $-T$. dobrogicus, red - T. cristatus, blue $-T$. ivanbureschi and purple-T. macedonicus. Morphological data are shown by unicolor round symbols and genetic data are shown by round symbols with a black interior dot. Concentric coloured circles represent hybrids identified from genetic data, with the outer circle corresponding to the species with the highest contribution to the population gene pool and the inner dots showing the species with the smaller contribution to the population gene pool. 
A hybrid status was found for $T$. dobrogicus $\times T$. cristatus at the Vršački breg Mt. (EQ29 - south-eastern Banat) and near Kladovo (FQ14 north-eastern Serbia); T. dobrogicus $\times$ T. ivanbureschi in Šumadija (DQ72 - foothills of Kosmaj Mt.); T. cristatus $\times$ T. ivanbureschi in north-eastern Serbia (EQ63 - near Kučevo and EP - near Žagubica). The most frequent were $T$. ivanbureschi $\times T$. macedonicus hybrids and these were predominantly distributed in the wide area of eastern and south-eastern Serbia around Dimitrovgrad, Pirot, Babušnica, Sokobanja, Sićevačka klisura gorge, as well as at the Stara planina Mt., the Suva planina Mt. and at the Vlasina Plateau (Fig. 1). Based on the mentioned criteria, admixed population of three species were also recorded, namely $T$. ivanbureschi $\times T$. macedonicus $\times T$. dobrogicus near Mionica (DQ20 - north-western Serbia) and $T$. ivanbureschi $\times$ T. macedonicus $\times T$. cristatus around Boljevac and at the foothills of the Rtanj Mt. (EP63 and EP74 - eastern Serbia) (Fig 1.).

\section{DISCUSSION}

Although the distribution of crested newts in Serbia was generally known from the previous publications (Arntzen 2003, Wielstra at al. 2014b, Kalezić et al. 2015, Džukić et al. 2016), this study provides an updated account on species distribution, including interspecific hybrid zones (Arntzen et al. 2014, Džukić et al. 2016).

However, as is clear from Fig. 1, there are still relatively large gaps apparent in the recording of some species. There are only a few records of T. macedonicus in western and south-western Serbia. For example, this species has not yet been recorded at following mountains: Mokra Gora Mt., Zlatibor Mt., Zlatar Mt., Kamena Gora Mt., Ozren Mt., Javor Mt., Mučanj Mt. and others, although T. macedonicus is expected in the mountain areas (Džukić et al. 2016). The absence of records could be due to the lack of suitable habitats, but also (and more likely) because of the lack of the research in these regions. The same stands for a large part of eastern Serbia (the surroundings of Zaječar, Knjaževac and Svrljig) where three species (and their hybrids) could occur: T. cristatus, T. ivanbureschi and $T$. macedonicus. More systematic faunistic research is also needed in Pomoravlje (around Požarevac, Svilajnac, Despotovac and Jagodina) and northeastern Serbia (the surroundings of Kučevo, Majdanpek and Donji Milanovac), in order to obtain a more precise view on the distribution of $T$. cristatus, T. ivanbureschi and T. dobrogicus, as well as the occurrence of hybrid zones between them. Future studies on the distribution of $T$. dobrogicus in the Peripannonian region, as well as of occurrence of hybrid populations of $T$. dobrogicus, T. ivanbureschi and T. macedonicus should 
be done in north-western Serbia (surroundings of Valjevo, Mionica, Ljig, Ub, Koceljeva, Šabac and Bogatić).

The frequency of hybrid populations reported in this study is probably largely underestimated. First, we set high threshold for defining hybrid population based on genetic data. Second, for most populations considered in this study only morphological data were available, which makes the recognition of hybrid populations almost impossible (Arntzen et al. 2018). Actually, a high level of gene flow and introgression characterises Triturus populations in Serbia (Wallis \& Arntzen 1989, Wielstra \& Arntzen 2012, Arntzen et al. 2014, Wielstra et al. 2017). In Serbia all T. macedonicus populations, except at Kosovo and Metohija, carry T. ivanbureshi mtDNA. The genetically admixed populations are almost all populations at the species contact zones, as well as the populations of $T$. ivanbureshi within the recognized enclave and populations of $T$. macedonicus took over from T. ivanbureshi. At the present state of faunistic and genetic research, the north-western, north-eastern, eastern and south-eastern parts of Serbia transpire as areas that are exceptionally important for the diversity of crested newts.

Further research is needed on the distribution and genetics of $T$. ivanbureschi populations in Šmadija region, which is crucial for further delineation of the T. ivanbureschi enclave, particularly the T. ivanbureschi - T. macedonicus contact zone along the Zapadna Morava river valley, which we presume is the natural barrier between these two species. The same holds for north-western Serbia where also three species come into contact. Another interesting problem is the possible spreading of the lowland species, $T$. dobrogicus, to the south along Velika Morava River valley and its hybridisation with other species as suggested by genetic data (Wielstra et al. 2017). More data for this species is required, from both Pannonian and Peripannonian plane, taking into account the population position relative to large rivers (Danube, Sava and Tisza) which were recognised as important geographical elements in shaping evolutionary history of amphibians (Vörös et al. 2016).

According to the IUCN criteria, T. cristatus, T. ivanbureschi and $T$. macedonicus are considered as least concerned species (LC), whereas $T$. dobrogicus is considered as near threatened (NT). All four species of crested newts are listed in Annex II of the Habitat Directive. The conservation status of the crested newts in Serbia is given in the Red Book of Fauna of Serbia I - Amphibians (Kalezić et al. 2015). Although all four Triturus species are strictly protected by law in the Republic of Serbia (Anonymous 2010a, b), the designation of areas of species distribution and the recognition of populations of special importance is the first and obligatory step for the improvement of the conservation statuses of crested 
newts in Serbia. The improvement of the conservation statuses of crested newts is extremely important due to rapid loss of suitable habitats. International scientific cooperation and mutual conservation actions are required for populations at the species contact zones which lay along the administrative borders of The Republic of Serbia with Romania ( $T$. dobrogicus and T. cristatus), Bulgaria (T. ivanbureschi and T. macedon$i c u s)$ and at the borders with Bosnia and Herzegovina, and Croatia ( $T$. dobrogicus and T. macedonicus).

Active conservation measures such as strict control in the field (by rangers and inspectors) and well-designed educational activities (from schoolchildren and laypeople to decision-makers) must also be undertaken, in order to achieve effective protection of all Triturus species as well as their natural habitats.

\section{Acknowledgements}

This study was partly funded through the projects: "Data collecting for implementation of Natura 2000 network in Republic of Serbia - JNOP 02/2019" and "EU for Serbia - Continued support to implementation of chapter 27 in the area of nature protection (Natura 2000)", and by the Serbian Ministry of Education, Science and Technological Development of the Republic of Serbia grant number 451-03-68/2020-14/200178. We are grateful to M. Kalezić, G. Džukić, I. Medenica and K. Stojanović for providing us with distribution data, as well as M. Lakušić, J. Stanković, M. Anđelković and M. Maričić for their assistance in the field work. We are grateful to: National park "Tara", Nature park "Stara Planina", Outstanding natural landscapes "Vlasina" and "Dolina Pčinje", Monument of nature "Lazarev Kanjon" for their logistic assistances. Data from the Internet were taken from the BIOLOGER database and we are thankful to those who provided the data: I. Tot, M. Popović, M. Maričić, M. Šćiban, I. Pančić, M. Mareš, A. Golubović and V. Dimitrijević. M. Niketić provided us the map of the distribution of Triturus species in Serbia. We thank J. W. Arntzen for constructive comments on the manuscript.

\section{REFERENCES}

Anonymous (2010a): Regulation on proclamation and protection of strictly protected and protected plant, animal and fungi species. - Official Gazette RS 5/10. [in Serbian]

Anonymous (2010b): Regulation on proclamation and protection of strictly protected and protected plant, animal and fungi species. Appendix 1. Strictly protected species. - Official Gazette RS 5/10. [in Serbian] 
Arntzen, J. W. (2003): Triturus cristatus Superspezies - Kammolch - Artenkreis (Triturus cristatus (Laurenti, 1768) - Nördlicher Kammolch, Triturus carnifex (Laurenti, 1768) - Italienischer Kammolch, Triturus dobrogicus (Kiritzescu, 1903) - Donau- Kammolch, Triturus karelinii (Strauch, 1870) - Südlicher Kammolch). In: Böhme W. (ed.): Handbuch der Reptilien und Amphibien Europas 4(2a): Schwanzlurche (Urodela): 421-514. - Aula-Verlag, Wiebelsheim, DE.

Arntzen, J. W., Sparreboom, M. (1989): A phylogeny for the Old World newts, genus Triturus: biochemical and behavioural data. - Journal of Zoology 219(4): 645-664.

Arntzen, J. W., Themudo, G. E., Wielstra, B. (2007): The phylogeny of crested newts (Triturus cristatus superspecies) nuclear and mitochondrial genetic characters suggest a hard polytomy, in line with the paleogeography of the centre of origin. - Contributions to Zoology 76: 261-278.

Arntzen, J. W., Üzüm, N., Ajduković, M. D., Ivanović, A, Wielstra, B. (2018): Absence of heterosis in hybrid crested newts. - PeerJ 6: e5317.

Arntzen, J. W., Vörös, J. (2010): Weak population structuring in the Danube crested newt, Triturus dobrogicus, inferred from allozymes. - AmphibiaReptilia 31: 339-346.

Arntzen, J. W., Wallis, G. P. (1994): The 'WOLTERSTORFF index' and its value to the taxonomy of the Crested Newt superspecies. - Abhandlungen und Berichte für Naturkunde 17: 57-66.

Arntzen, J. W., Wallis, G. P. (1999): Geographic variation and taxonomy of crested newts (Triturus cristatus superspecies): morphological and mitochondrial DNA data. - Contributions to Zoology 63: 181-203.

Arntzen, J. W., Wielstra, B. (2010): Where to draw the line? A nuclear genetic perspective on proposed range boundaries of the crested newts Triturus karelinii and T. arntzeni. - Amphibia-Reptilia 31: 311-322.

Arntzen, J. W., Wielstra, B., Wallis, G. P. (2014): The modality of nine Triturus newt hybrid zones assessed with nuclear, mitochondrial and morphological data. - Biological Journal of the Linnean Society 113: 604-622.

Borkin, L. J., Litvinchuk, S. N. (2000): Intraspecific taxonomy and nomenclature of the Danube crested newt, Triturus dobrogicus. - Amphibia-Reptilia 21(4): 419-430.

Bolkay, J. (1928): Die Schädel der Salamandrinen, mit besonderer Rücksicht auf ihre systematische Bedeutung. - Anatomy and Embryology 86: 259-319. [in German]

Bucci-Innocenti, S., Ragghianti, M., Mancino, G. (1983): Investigations of karyology and hybrids in Triturus boscai and T. vittatus, with a reinterpretation of the species groups within Triturus (Caudata: Salamandridae). - Copeia 1983(3): 662-672.

Crnobrnja, J., Kalezić, M. L., Džukić, G. (1989): Genetic divergence in the crested newt (Triturus cristatus complex) from Yugoslavia. - Biosistematika 15: 81-92.

Džukić, G., Vukov, T. D., Kalezić, M. L. (2016): Repati vodozemci Srbije. Srpska akademija nauka i umetnosti, Beograd, RS. [in Serbian] 
García-París, M., Montori, A., Herrero, P. (2004): Fauna ibérica: Amphibia: Lissamphibia 24. - Museo Nacional de Ciencias Naturales, Madrid, ES. [in Spanish]

Giacoma, C., Balletto, E. (1988): Phylogeny of the salamandrid genus Triturus. Italian Journal of Zoology 55(1-4): 337-358.

Halliday, T. R. (1997): The courtship of European newts: an evolutionary perspective. In: Taylor, D. H., Guttman, S. I. (ed.): The reproductive biology of amphibians: 185-232. - Springer, USA.

Kalezić, M. L., Hedgecock, D. (1980): Genetic variation and differentiation of three common European newts (Triturus) in Yugoslavia. - British Journal of Herpetology 6: 49-57.

Kalezić, M., Tomović, Lj., Džukić, G. (ed.) (2015): Red Book of Fauna of Serbia I - Amphibians: 1-207. - University of Belgrade - Faculty of Biology \& Institute for Nature Conservation of Serbia, Belgrade, RS.

Kalezić, M. L., Džukić, G., Mesaroš, G., Crnobrnja-Isailović, J. (1997): The crested newt (Triturus cristatus superspecies) in ex-Yugoslavia: morphological structuring and distribution patterns. - University Thoughts Natural Science Priština 4: 39-46.

Kalezić, M. L., Džukić, G., Stamenković, S., Crnobrnja, J. (1990): Morphometrics of the crested newt (Triturus cristatus complex) from Yugoslavia: Relevance for taxonomy. - Archives of Biological Sciences 42: 17-37.

Litvinchuk, S. N., Borkin, L. J., Džukić, G., Kalezić, M. L., Khalturin, M. D., Rosanov, J. M. (1999): Taxonomic status of Triturus karelinii on the Balkans, with some comments about other crested newt taxa. - Russian Journal of Herpetology 6: 153-163.

Litvinchuk, S. N., Zuiderwijk, A., Borkin, L. J., Rosanov, J. M. (2005): Taxonomic status of Triturus vittatus (Amphibia: Salamandridae) in western Turkey: trunk vertebrae count, genome size and allozyme data.-Amphibia-Reptilia 26:305-324.

Naumov, B., Biserkov, V. (2013): On the distribution and subspecies affiliation of Triturus dobrogicus (Amphibia: Salamandridae) in Bulgaria. - Acta Zoologica Bulgarica 65: 307-313.

Niketić, M. (1999): Software application for the taxon threat estimation. In: Stevanović, V. (ed.): The Red Data Book of Flora of Serbia 1. Extinct and critically endangered taxa: 32-39, 406-407. - Ministry of Environment of the Republic of Serbia, Faculty of Biology, University of Belgrade, Institution for protection of nature of the Republic of Serbia, Belgrade. [In Serbian with English Summary]

Popović, M., Vasić, N., Koren, T., Burić, I., Živanović, N., Kulijer, D., Golubović, A. (2020): Biologer: an open platform for collecting biodiversity data. Biodiversity Data Journal 8: e53014.

Rafiński, J., Arntzen, J. W. (1987): Biochemical systematics of the Old World newts, genus Triturus: allozyme data. - Herpetologica 43: 446-457.

Steinfartz, S., Vicario, S., Arntzen, J. W., Caccone, A. (2007): A Bayesian approach on molecules and behavior: reconsidering phylogenetic and evolutio- 
nary patterns of the Salamandridae with emphasis on Triturus newts. - Journal of Experimental Zoology Part B: Molecular and Developmental Evolution 308: $139-162$.

Themudo, G. E., Wielstra, B., Arntzen, J. W. (2009): Multiple nuclear and mitochondrial genes resolve the branching order of a rapid radiation of crested newts (Triturus, Salamandridae). - Molecular Phylogenetics and Evolution 52: 321-328.

Titus, T. A., Larson, A. (1995): A molecular phylogenetic perspective on the evolutionary radiation of the salamander family Salamandridae. - Systematic Biology 44: 125-151.

Vörös, J., Arntzen, J. W. (2010): Weak population structuring in the Danube crested newt, Triturus dobrogicus, inferred from allozymes. - AmphibiaReptilia 31: 339-346.

Vörös, J., Mikulíček, P., Major, A., Recuero, E., Arntzen, J. W. (2016): Phylogeographic analysis reveals northerly refugia for the riverine amphibian Triturus dobrogicus (Caudata: Salamandridae). - Biological Journal of the Linnean Society 119: 974-991.

Wake, D. B., Özeti, N. (1969): Evolutionary relationships in the family Salamandridae. - Copeia 1969: 124-137.

Wallis, G. P., Arntzen, J. W. (1989): Mitochondrial DNA variation in the crested newt superspecies: limited cytoplasmic gene flow among species. - Evolution 43: $88-104$.

Weisrock, D. W., Papenfuss, T. J., Macey, J. R., Litvinchuk, S. N., Polymeni, R., Ugurtas, I. H., Larson, A. (2006): A molecular assessment of phylogenetic relationships and lineage accumulation rates within the family Salamandridae (Amphibia, Caudata). - Molecular Phylogenetics and Evolution 41: 368-383.

Wielstra, B., Arntzen, J. W. (2011): Unraveling the rapid radiation of crested newts (Triturus cristatus superspecies) using complete mitogenomic sequences. BMC Evolutionary Biology 11: 1-8.

Wielstra, B., Arntzen, J. W. (2012): Postglacial species displacement in Triturus newts deduced from asymmetrically introgressed mitochondrial DNA and ecological niche models. - BMC Evolutionary Biology: 161.

Wielstra, B., Arntzen, J. W. (2014): Kicking Triturus arntzeni when it's down: large-scale nuclear genetic data confirm that newts from the type locality are genetically admixed. - Zootaxa 3802: 381-388.

Wielstra, B., Arntzen, J. W. (2016): Description of a new species of crested newt, previously subsumed in Triturus ivanbureschi (Amphibia: Caudata: Salamandridae). - Zootaxa 4109(1): 73-80.

Wielstra, B., Baird, A. B., Arntzen, J. W. (2013a): A multimarker phylogeography of crested newts (Triturus cristatus superspecies) reveals cryptic species. Molecular Phylogenetics and Evolution 67: 167-175.

Wielstra, B., Litvinchuk, S. N., Naumov, B., Tzankov, N., Arntzen, J. W. 2013 b. (2013b): A revised taxonomy of crested newts in the Triturus karelinii group 
(Amphibia: Caudata: Salamandridae), with the description of a new species. Zootaxa 3682: 441-453.

Wielstra, B., Arntzen, J. W., van der Gaag, K. J., Pabijan, M., Babik, W. (2014a): Data concatenation, bayesian concordance and coalescent-based analyses of the species tree for the rapid radiation of Triturus newts. - PloS One 9: e111011.

Wielstra, B., Sillero, N., Vörös, J., Arntzen, J. W. (2014b): The distribution of the crested and marbled newt species (Amphibia: Salamandridae: Triturus) - an addition to the New Atlas of Amphibians and Reptiles of Europe. - AmphibiaReptilia 35: 376-381.

Wielstra, B., Duijm, E., Lagler, P., Lammers, Y., Meilink, W. R. M., Ziermann, J. M., Arntzen, J. W. (2014c): Parallel tagged amplicon sequencing of transcriptome-based genetic markers for Triturus newts with the Ion Torrent nextgeneration sequencing platform. - Molecular Ecology Resources 14: 10801089.

Wielstra, B., Beukema, W., Arntzen, J. W., Skidmore, A. K., Toxopeus, A. G., Raes, N. (2012): Corresponding mitochondrial DNA and niche divergence for crested newt candidate species. - PloS One 7(9): e46671.

Wielstra, B., Burke, T., Butlin, R. K., Arntzen, J. W. (2017): A signature of dynamic biogeography: enclaves indicate past species replacement. - Proceedings of the Royal Society of London. Series B: Biological Sciences 284: 20172014.

Wielstra, B., McCartney-Melstad, E., Arntzen, J. W., Butlin, R. K., Shaffer, H. B. (2019): Phylogenomics of the adaptive radiation of Triturus newts supports gradual ecological niche expansion towards an incrementally aquatic lifestyle. - Molecular Phylogenetics and Evolution 133: 120-127.

Wielstra, B., Themudo, G. E., Güclü, Ö., Olgun, K., Poyarkov, N. A., Arntzen, J. W. (2010): Cryptic crested newt diversity at the Eurasian transition: the mitochondrial DNA phylogeography of Near Eastern Triturus newts. Molecular Phylogenetics and Evolution 56: 888-896.

Wielstra, B., Vörös, J., Arntzen, J. W. (2016): Is the Danube crested newt Triturus dobrogicus polytypic? A review and new nuclear DNA data. - AmphibiaReptilia 37(2): 167-177.

Wiens, J. J., Sparreboom, M., Arntzen, J. W. (2011): Crest evolution in newts: implications for reconstruction methods, sexual selection, phenotypic plasticity and the origin of novelties. - Journal of Evolutionary Biology 24: 2073-2086.

Wolterstorff, W. (1923): Übersicht den Unterarten und Formen des Triton cristatus Laur. - Blätter für Aquarien- und Terrarien-kunde 34: 120-126. [In German]

Zajc, I., Arntzen, J. W. (1999): Phylogenetic relationships of the European newts (genus Triturus) tested with mitochondrial DNA sequence data. - Contributions to Zoology 68: 73-82.

Zhang, P., Papenfuss, T. J., Wake, M. H., Qu, L., Wake, D. B. (2008): Phylogeny and biogeography of the family Salamandridae (Amphibia: Caudata) inferred from complete mitochondrial genomes. - Molecular Phylogenetics and Evolution 49: 586-597. 


\title{
SUPPORTING INFORMATION
}

\section{Online Appendices:}

Appendix 1. - Distribution records of four Triturus species and their hybrids (Tcri - T. cristatus, Tdob - T. dobrogicus, Tiva - T. ivanbureschi, Tmac $-T$. macedonicus) in the Republic of Serbia with: regions, broad locations, exact localities, toponyms, UTM $10 \times 10 \mathrm{~km}$ squares, longitudes, latitudes, altitudes, legators and dates of observations; L - literature sources, I - internet sources, F - field data; * - available genetic data; $\mathrm{r}$ - river, v - village.

\section{ДИСТРИБУЦИЈА ВЕЛИКИХ МРМОЉАКА У СРБИЈИ: ПРЕГЛЕД И ДОПУНА}

\author{
ТИЈАНА ВУЧИЋ. ЉИљАНА ТОМОВИЋ, АНА ИВАНОВИЋ
}

\author{
Р Е 3 И М Е
}

Род Triturus, чини група од девет врста великих мрмољака од којих четири живе у Србији: Triturus cristatus, T. dobrogicus, T. ivanbureshi и T. macedonicus. Ове врсте, са парапатричком дистрибуцијом, на местима контакта формирају комплексан систем хибридних зона. Због велике сличности, детерминација врста на основу спољашње морфологије је непоуздана, нарочито у хибридним зонама. Посебан проблем у утврђивању дистрибуције је неусаглашеност података доступних у литератури, базама података и законској легислативи, до којих је дошло услед низа узастопних промена у таксономији.

Циљ овог рада је да пружи кратак историјски преглед проблематике таксономије великих мрмољака; прикупи све доступне фаунистичке податке, систематизује их и представи у виду UTM карте дистрибуције $(10 \times 10 \mathrm{~km})$; да поред дистрибуције врста назначи зоне контакта и хибридне популације, као и да пружи смернице за будућа фаунистичка истраживања. 
Прикупљено је укупно 495 фаунистичка податка. Triturus macedonicus је најзаступљенија врста са $39.8 \%$ уноса, затим $T$. dobrogicus ca $30.9 \%$, T. cristatus ca $10.1 \%$ уноса и $T$. ivanbureschi ca $9.7 \%$ уноса. Најмање су заступљене хибридне популације са $9.5 \%$ уноса.

На основу добијене дистрибуције јасно су уочљиве зоне од значаја за будућа фаунистичка истраживања. То су пре свега области у којима у потпуности недостају подаци о присуству великих мрмољака, као што су делови западне и југозападне Србије. Велике области северозападне, североисточне и источне Србије, као и Поморавља, посебно су интересантне са аспекта хибридизације, генетичке варијабилности и диверзитета великих мрмољака. Додатна фаунистичка и генетичка истраживања у оквиру ових области су неопходна да би се прецизније утврдила дистрибуција врста, генетички диверзитет популација и омогућила њихова адекватна заштита. 